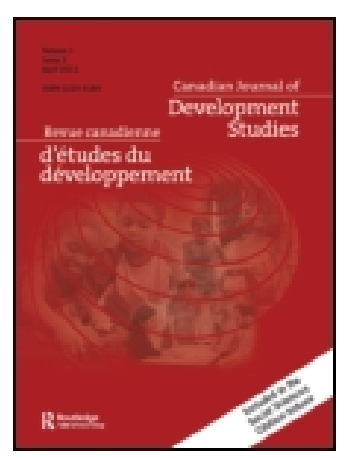

Canadian Journal of Development Studies/ Revue canadienne d\&apos;\&eacute;tudes du d\&eacute; veloppement

\title{
Patterns of Financial Capital Flows and Accumulation in the Post-1990 Turkish Economy
}

\section{F. Gül Biçcr \& Erinç Yeldan}

To cite this article: F. Gül Biçcr \& Erinç Yeldan (2003) Patterns of Financial Capital Flows and Accumulation in the Post-1990 Turkish Economy, Canadian Journal of Development Studies/ Revue canadienne d\&apos;\&eacute;tudes du d\&eacute;veloppement, 24:2, 249-265, DOI: 10.1080/02255189.2003.9668915

To link to this article: https://doi.org/10.1080/02255189.2003.9668915

\section{册 Published online: 15 Feb 2011.}

Submit your article to this journal $\widetilde{3}$

Џ Article views: 65 


\title{
Patterns of Financial Capital Flows and Accumulation in the Post-1990 Turkish Economy*
}

\author{
F. Gül Biçer ${ }^{\dagger}$ and \\ Erinç Yeldan ${ }^{\ddagger}$
}

\begin{abstract}
The purpose of this paper is twofold: using time series econometrics, we first investigate the determinants of short-term foreign capital inflows for Turkey following its capital account liberalization in 1989. We next investigate the changing nature of the private investment function under post-capital account liberalization and deduce hypotheses on its correlation with capital inflows and the key macroeconomic prices, such as the exchange rate, the real rate of interest, and real wages.

Our results suggest that financial capital inflows have a significant negative correlation with the industrial production index and trade openness, and are positively correlated with real currency appreciation. Fixed private investment was found to have an inconclusive relationship with financial capital inflows. Real wage costs were observed to carry a significant negative relationship with private investment, indicating that at a time of currency appreciation, investors had to rely on declining wage costs in order to keep their export competitiveness. Under the volatile and uncertain conditions of speculation-driven investment patterns, the downward flexibility of real wages has to be seen as a concomitant factor of the post-financial liberalization episodes.
\end{abstract}

RESUME - Le but de cet article est double. D'abord, au moyen de l'économétrie de séries chronologiques, nous étudions les facteurs déterminants de l'afflux des capitaux étrangers à court terme en Turquie durant la période qui a suivi la libéralisation des comptes de capital en 1989. Ensuite, nous étudions la fonction changeante des investissements privés durant cette période de libéralisation pour en déduire des hypothèses concernant sa corrélation avec l'afflux des capitaux et les principaux prix macroéconomiques comme le taux de change, le taux d'intérêt réel et les salaires réels.

Nos résultats laissent penser qu'il existe une corrélation négative significative entre l'afflux des capitaux financiers et l'indice de la production industrielle et la liberté du commerce, mais une corrélation positive avec l'appréciation de la monnaie réelle. Il n'y a toutefois pas de rapport concluant entre l'investissement privé fixe et l'afflux des capitaux financiers. Nous avons observé que l'investissement privé a un rapport négatif significatif avec les coûts salariaux

* Paper presented at the International Development Economics Associates (IDEAs: <www.networkideas.org>) session at Middle East Technical University (METU) International Conference on Economics, VI, Ankara, September 2002. We are grateful to Erol Balkan, Fikret Senses, Umit Ozlale, Kivilcim Metin-Özcan, Korkut Boratav, and to colleagues at Bilkent and IDEAS for their valuable comments and insights. Author names are in alphabetical order and do not necessarily represent authorship seniority.

$\dagger \quad$ F. Gül Biçer is a graduate student and research assistant in the Department of Economics at Bilkent University, Ankara, Turkey. Her research interests are development economics, applied econometrics, and international finance. She can be reached at <bicer@bilkent.edu.tr >.

‡ Erinç Yeldan is Professor of Economics and Chair of the Department of Economics at Bilkent University, Ankara, Turkey. He received his pho from the University of Minnesota, Twin-Cities. His research interests are development macroeconomics, applied general equilibrium modelling, and international economics. He can be reached at <yeldane@bilkent.edu.tr>. 
réels. Ceci laisse supposer qu'en période d'appréciation de la monnaie, les investisseurs ont dû compter sur une diminution des coûts salariaux pour garder leur compétitivité à l'exportation. Dans des conditions volatiles et incertaines où la spéculation mène les modèles d'investissement, la flexibilité à la baisse des salaires réels doit être vue comme un facteur concomitant des épisodes qui suivent la libéralisation financière.

\section{INTRODUCTION}

The 1990s witnessed a surge in capital flows to the developing countries. As measured by the surplus on the capital account, the developing countries of Latin America and Asia alone received a sum of Us $\$ 670$ billion of foreign capital from 1990 to 1994 (Calvo, Leiderman and Reinhart 1996). Net flows diminished significantly in 1995 in the aftermath of the Mexican crisis, but in most cases surged once again to reach high levels by the end of the decade. Furthermore, a structural shift was observed in the composition of the private flows, with portfolio and other short-term capital flows gaining importance (UNCTAD 1998).

Theory asserts that increased integration of the world capital markets is conducive to growth and is expected to improve general welfare. Capital flows are expected to expand investors' portfolio diversification, while simultaneously enabling consumers to smooth out their consumption - saving decisions over their life cycle. The historical experience, however, suggests otherwise. Muddled with myopia and the speculative herd behaviour of domestic and foreign financial arbiters, the recent financial crises across Latin America and Asia demonstrate the dangers of premature liberalization. Such attempts led those economies to be extremely vulnerable to the in- and outflows of short-term foreign capital, which, in itself, is excessively liquid, excessively volatile, and is subject to herd psychology.

In fact, the variety of crisis experiences of the developing-country during the post-capital account liberalization era reveals the dangers of unregulated short-term speculative capital flows to the macro fundamentals of the recipient countries. In the words of the United Nations Conference on Trade and Development's (UNCTAD) 1998 Trade and Development Report, "the ascendancy of finance over industry together with the globalization of finance have become underlying sources of instability and unpredictability in the world economy ... In particular, financial deregulation and capital account liberalization appear to be the best predictor of crises in developing countries" $(v, 55)$. Almost all recent episodes of financial-cum-currency instability disclose that the observed sharp swings in capital flows are primarily a reflection of large discrepancies between domestic financial conditions and those of the rest of the world. Reversals of capital flows are often associated with deterioration of the macroeconomic fundamentals in the recipient country. However, "such deterioration often results from the effects of capital inflows themselves as well as from external developments, rather than from shifts in domestic macroeconomic policies" (UNCTAD 1998, 56).

Finally it was also noted that while the post-financial liberalization episodes are characterized by very large gross capital flows, they have generated rather small net transfers. As is also remarked by Tobin (2000), net capital flows from the developed to the underdeveloped economies had been only on the order of US $\$ 150$ billion per annum during the $1990 \mathrm{~s}$. One can contrast this figure with the daily volume of speculative foreign exchange transactions reaching to US\$ 1.8 trillion. It is now a well-known fact that the gross volume of international capital flows across the national boundaries is far in excess of the financing needs of commodity trade flows or investments on physical capital, and is mostly driven by speculative considerations of risk hedging and currency speculation. For instance, using data of 32 emerging markets from 1988-98, Rodrik and Velasco $(2000,61)$ report that “... there does not appear to be any relationship between the volume of international trade and the level of short term debt - suggesting that trade credit has played little or no role in driving shortterm capital flows during the 1990s." 
Thus, under this characterization of the post-financial liberalization episodes, large capital inflows as witnessed in recent years have posed serious dilemmas and created significant policy challenges. Indeed, the recent history of the financial crises in the "successful emerging markets" clearly demonstrates the undesirable macroeconomic effects of large, uncontrolled capital inflows, as evidenced by the persistence of high real interest rates, inflationary pressures, the limitation of the power of the central banks to contain the pressures of monetary expansion and of the threat of currency substitution, real exchange rate appreciation, and widening current account deficits.

This paper attempts to address these issues and investigates the determinants of short-term foreign capital inflows for Turkey following its capital account liberalization in 1989. Turkey's postfinancial liberalization history of macroeconomic and political developments remains as an enigmatic deepening of its crisis-prone fragility - with persistent price inflation, persistent and rapidly expanding fiscal deficits, and increased volatility of its gross domestic product (GDP). We identify capital inflows exclusively with the portfolio investments of residents and non-residents abroad and with banking sector short-term foreign credits; and using time-series econometrics, we search for the macroeconomic variables that best explain the behaviour of capital inflows over the period from 1992 to 2002. We further investigate the changing nature of the private investment function under post-capital account liberalization and deduce hypotheses on its correlation with capital flows and the key macroeconomic prices, such as the exchange rate, the real rate of interest, and real wages.

The plan of the paper is as follows: in section I we study the historically observed features of foreign (financial) capital inflows into Turkey during the 1990s. The econometric methodology is introduced in section II. Here we use time-series econometrics to study the behaviour of financial capital flows and private fixed investments against key macroeconomic indicators. We then present our conclusions.

\section{Financial Capital Inflows and Key MACROECONOMIC INDICATORS OF TURKEY}

Turkey liberalized its capital account in 1989. The manoeuvre paved the way for the injection of liquidity into the domestic asset markets in the form of short-term foreign capital (flows of "hot money"). Net portfolio investments fluctuated abruptly through the 1990 s between us $\$+3.9$ billion (1993) and US\$ -6.7 billion (1998); and then again between US $\$+3.4$ billion (1999) and US\$ -4.5 billion (2001). Such inflows enabled the financing of accelerated public expenditures, and also provided temporary relief from the increased pressures of aggregate demand on the domestic goods markets by cheapening the cost of imports. By contrast, long-term foreign direct investment (FDI) performance was meagre, never crossing the US $\$ 1$ billion mark, save for the exceptional period of 2001. Table 1 summarizes the salient features of the capital flows and the key macro aggregates.

We focus on three aspects of short-term capital inflows: (1) short-term foreign credits obtained by the banking sector, and inflows due to (2) security sales of residents abroad, and (3) security purchases of non-residents in Turkey. Data available for the Turkish banking sector's short-term foreign credits date to 1991, and for portfolio investments of residents and non-residents to 1992. It is interesting to note that net flows of securities by residents yield a negative figure almost throughout the 1990s, with the exception of 1994 . On the liability side, net flows of security purchases of non-residents in Turkey yield positive - yet modest - magnitudes until 1997. In 1998 and then again in the aftermath of the November 2000 and February 2001 crises, the net balance on non-residents' security purchases turns severely negative. Thus, totalling from 1992 to the end of 2001 , one finds that the cumulative net flows of securities by residents and 


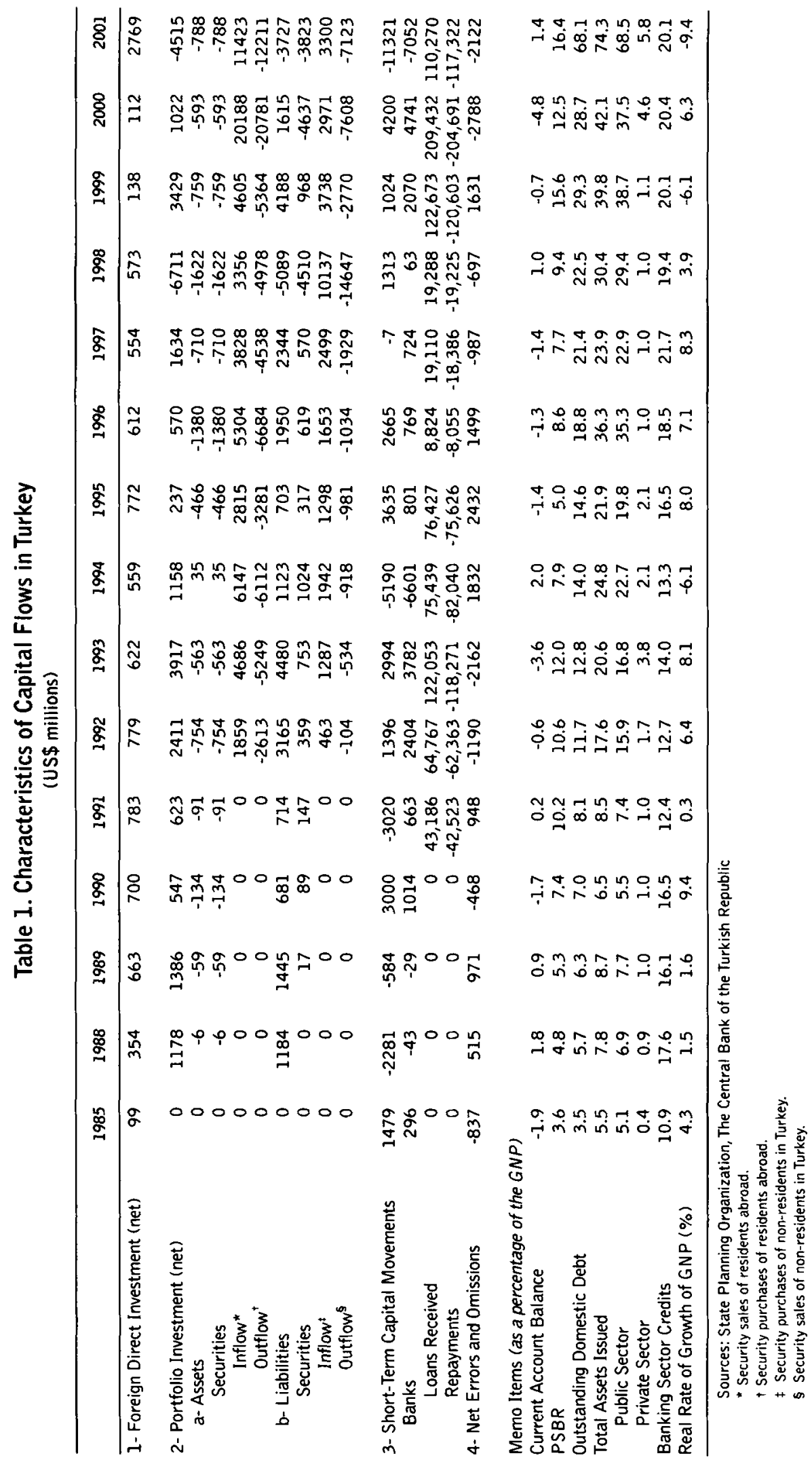


non-residents combined reach US $\$-15.9$ billion. The extent of the net transfer of liquid funds from Turkey to the global financial centres has, indeed, been substantial. We portray the paths of the gross in- and out-flows of short-term speculative foreign capital along with their net magnitudes in figures $\mathrm{la}$ and $\mathrm{lb}$. The "volatility engine" (Bello et al. 2000) of short-term capital flows with a significant hot component is clearly visible.

Figure 1a. Portfolio Investments: SecuritiesSales (Inflows) and Purchases

(Outflows) by Residents, Abroad

(Millions USS)

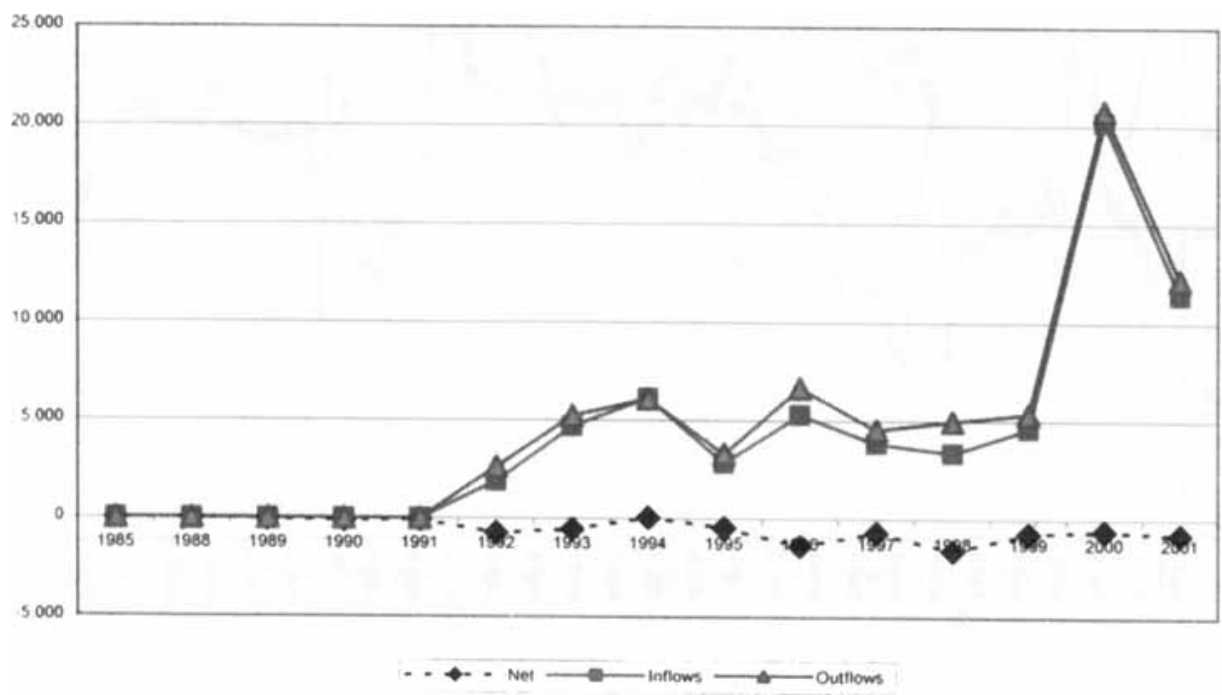

Figure 1.b Portfolio Investments: Securities Purchases (Inflows) and Sales (Outflows) by Non-Residents in Turkey

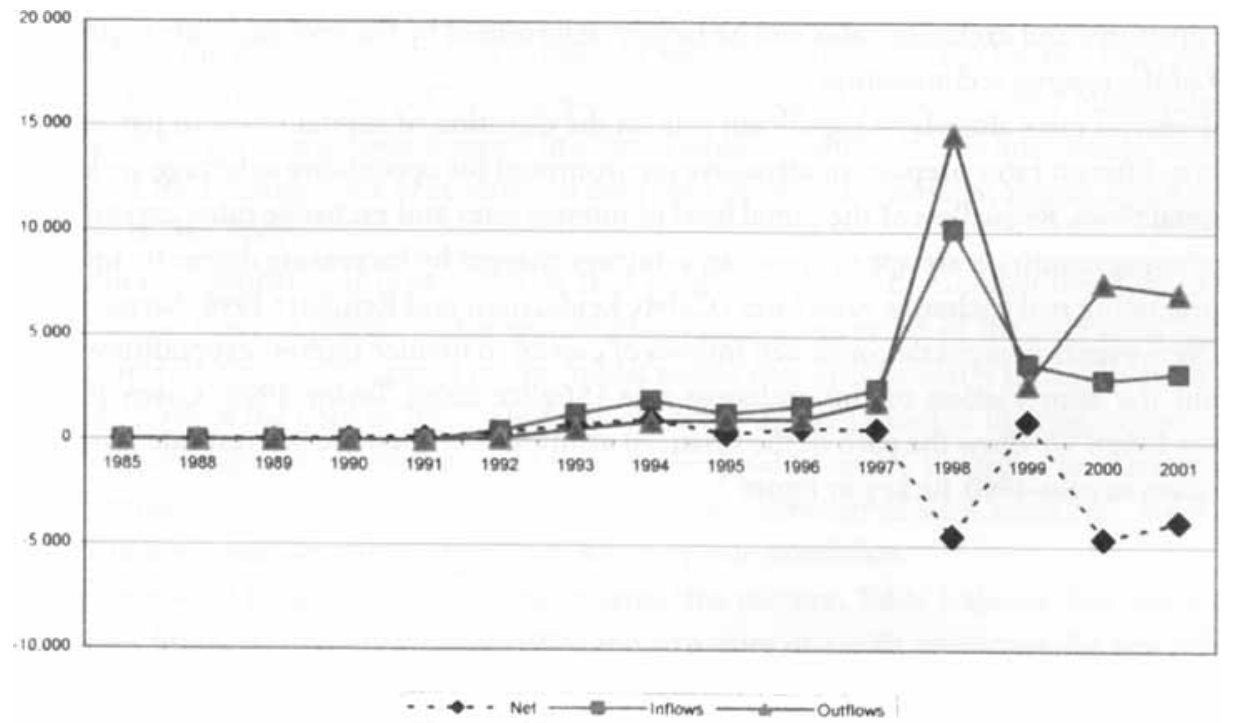


One of the significant consequences of the hot money flows just identified pertains to the appreciation of the domestic currency, the Turkish lira (TRL). After the inception of capital account liberalization, the Turkish lira is observed to be mostly on an appreciation trend (see figure 2). Özlale and Yeldan (2002), for instance, report that the appreciation of the Turkish lira reached $18 \%$ over the period from 1989 to May $2002 .{ }^{1}$

Figure 2. Real Exchange Rate, Turkey $(1987=100)$

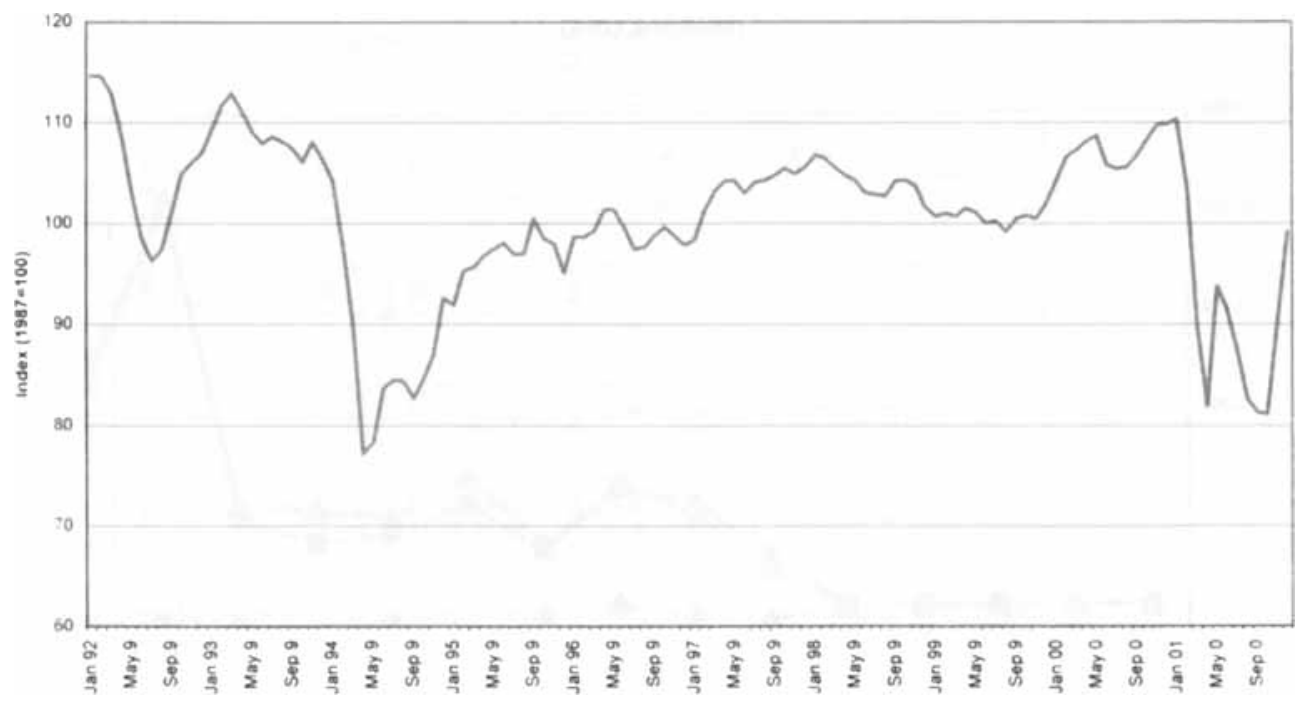

Note: An increase indicates appreciation of TL.

Source: Central Bank of Turkey

According to standard open economy models, increases in consumption and investment are associated with appreciation of the real exchange rates. Driven by the ease of access to foreign exchange, the increase of aggregate demand generates inflationary pressures with real exchange rate appreciation and a widening of the current account deficit. However, the resulting effects on inflationary pressures and exchange rates will be largely determined by the exchange rate regime and the amount of the reserve accumulation.

Real interest rates also play a significant role on the direction of capital flows. In particular, high, short-term interest rates prepare an attractive environment for speculative arbitrage seeking shortterm capital flows. Regardless of the initial level of interest rates and exchange rates, capital inflows to the developing countries are apt to create an arbitrage margin by increasing domestic interest rates and appreciating real exchange rates later (Calvo, Leiderman and Reinhart 1996; Sarno and Taylor 1999). These events necessitate continued inflows of capital to finance interest expenditures as well as to sustain the appreciation of the exchange rate (Stiglitz 2000; Taylor 1998; Calvo 1998; DiazAlejandro 1985). We show the path of the financial arbitrage between the interest rate ${ }^{2}$ and currency depreciation in post-1990 Turkey in figure 3.

1. Based on Purchasing Power Parity (PPP) comparison of the Turkish lira against the us dollar, and using the wholesale price index $(1989=100)$.

2. Three-month compounded rate of interest on government debt instruments (GDIs). 
Vigure 3. Rate of Financial Arbitrage (\%)

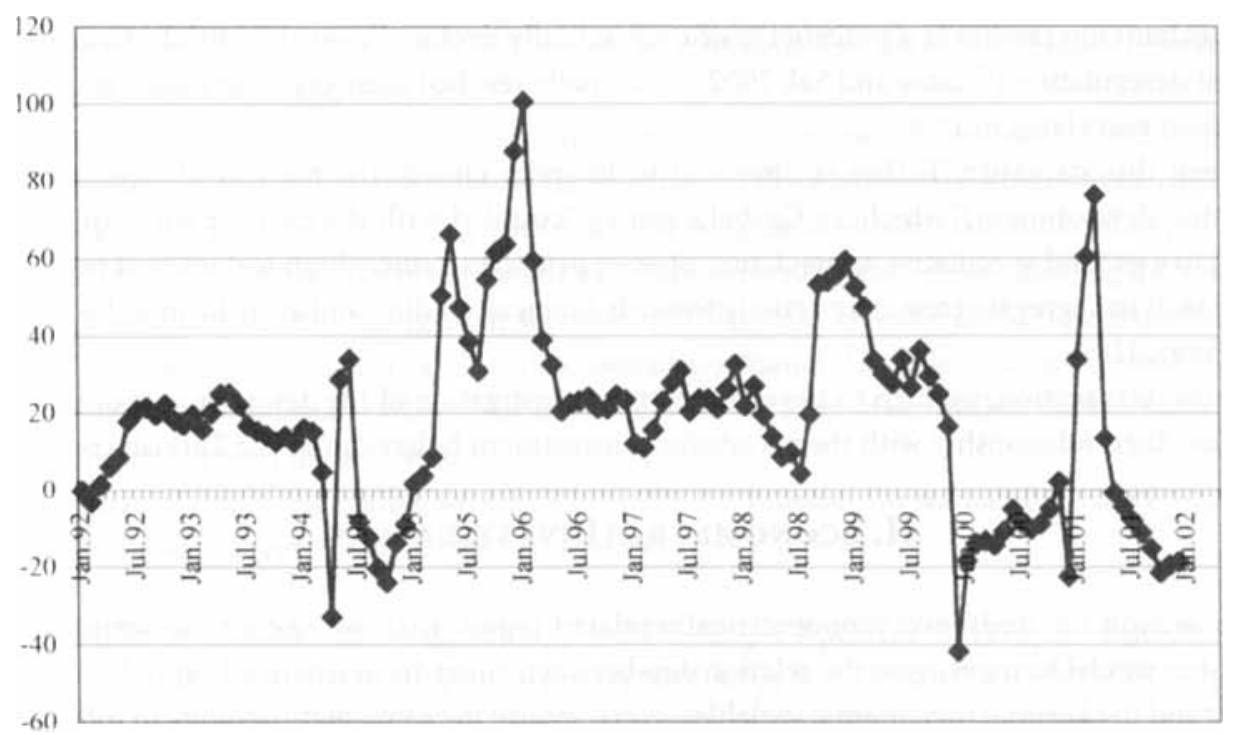

In table 1 we also provide key macroeconomic aggregates. We note that even though the balance on the current account has been mostly on the negative side, its size nevertheless was rather modest as a ratio to the gross national product (GNP). Except for the pre-crisis years of 1993 and 2000, the size of the current account deficits has been on the order of less than $1.5 \%$ of the GNP, suggesting that the national saving-investment gap has not been severely binding. Yet the high sensitivity of the financial arbiters to the balance on the current account is clearly visible, in that both surges of the current account deficits in 1993 (with 3.6\%) and in 2000 (with 4.8\%) were associated with sudden reversals of hot money flows and the concomitant financial crises of 1994 and 2001.

The public sector borrowing requirement (PSBR) constituted another source of fragility. As a ratio to the GNP, the PSBR has been on a continued upward spiral - except for two brief periods of deceleration in 1994/1995 and 1997. Consequently, the stock of domestic debt outstanding rose sharply. In fact, Turkey was already trapped in a Ponzi situation with net new borrowings reaching as high as $50 \%$ of the existing stock of securitized debt over the decade (Boratav, Yeldan, and Köse 2001; Voyvoda and Yeldan 2002).

Under these conditions, it is no surprise that public securities dominated the domestic asset markets, with the share of private sector securities remaining below $1 \%$ of the GNP until late in the decade. In contrast, new assets issued by the public sector rose spectacularly throughout the $1990 \mathrm{~s}$, and reached $37.5 \%$ of the GNP in 2000 . Thus, the observed upward trend of the proportion of direct securities to GNP originated from the direct new issues of public sector securities and Treasury bills. Since the commercial banking system has been the major customer of such securities, however, the major share of aggregate security instruments fell in private portfolios.

The behaviour of banking credits complements this picture. Table 1 shows that following the completion of financial liberalization in 1989, the structure of credit financing did not reveal any significant change. Indeed, throughout the course of these events, Turkish banks became detached from their conventional functions and started to act as institutional rentiers. They were able to make 
huge arbitrage gains when conditions were appropriate (Boratav, Yeldan, and Köse 2001; Önis and Aysan 2000; Yentürk 1999), but became extremely vulnerable to exchange rate risks and to sudden changes in the inflation rate. The ratio of credit to liabilities was adversely affected in this environment, as banking credits as a percentage of GNP actually declined over the initial phase of capital account deregulation (Özatay and Sak 2002), and finally reached their pre-liberalization share again only seven years later, in 1996.

Given this structure, Turkey is observed to fit quite closely the pattern of "speculation-led economic development," which, in Grabel's words, "coupled with the ensuing investor euphoria, [leads] to a general speculative appreciation of asset prices, extremely high real interest rates, and an overall shift in aggregate economic activity towards financial trading and away from industrial activities" $(1995,128)$.

In the next section, we turn to the econometric investigation of the determinants of hot money flows and their relationship with the private fixed investment behaviour in the Turkish context.

\section{ECONOMETRIC INVESTIGATION}

In this section we study two econometrically related issues: first, we use a time-series, multiple regression model to investigate the relationship between short-term financial capital (hot money) inflows and the key macroeconomic variables. Next, we use the same methodology to infer the relationship between private fixed investments and the hot money inflows, together with the key macroeconomic prices.

\section{A. The Relationship Between Financial Capital Inflows and Macroeconomic Variables}

The time series investigated in the first model is composed of the monthly data of the index of the Istanbul Stock Exchange National-100 (IMKB), the real exchange rate (RER), the real interest rate (REINTWPI), the ratio of the budget balance to GNP (BUDBAGNP), the industrial production index (IP), and the degree of trade openness (OPENNESs). The dependent variable is the gross inflows of short-term foreign financial capital (GROSSINF). This is the sum of portfolio investments by residents' security sales abroad, non-residents' security purchases in Turkey, and the gross inflows of banking sector short-term foreign credits. All of the variables are monthly observations covering the period from January 1992 to December 2001 (120 observations in all).

The performance of the stock exchange markets is regarded as one of the key variables in relation to short-term capital inflows, and hot money-led speculative stock market bubbles are common parlance in the literature. ${ }^{3}$ We use the index of the Istanbul Stock Exchange National-100 for capturing this relationship. The real interest rate variable is estimated from the three-month compounded nominal interest rates of T-bills deflated by the wholesale price index. To measure the effectiveness of fiscal policy and the effects of fiscal balances, we used the lagged value of the ratio of the budget balance to GNP. Since the original data for GNP was annual, we used a seasonal adjustment to convert it to monthly. The industrial production index was used to measure whether capital flows are correlated with increases in industrial production. We further used the lagged value

3. See Balkan and Yeldan (1998) for an analysis of gross short-term capital inflows and the index of the Istanbul Stock Exchange Market. 
of the dependent variable, because the accelerated capital flows create an effect on itself. The relationship of the openness of the economy with capital inflows is estimated using the ratio of the sum of the absolute values of export and import to GNP.

Finally, three dummies were used to capture the effects of the three downturns of the business cycle, namely 1994, 1998, and 2001.

The first step in the econometric investigation is to select the appropriate model to estimate financial capital inflows. In order to choose the best model from among the alternatives, we used the method of general-to-specific: starting from a general congruent model, standard testing procedures are used to eliminate statistically insignificant variables, with diagnostic tests checking the validity of reductions, reaching the final congruent selection (Krolzig and Hendry 2001). The model with the best Akaike Information Criteria (AIC) and Schwarz Information Criteria (SIC) is selected using this method. We have found that, rather than working with the level magnitudes, the log values of the variables improved both the AIC and SIC, and also the $\mathrm{R}^{2}$. $^{4}$

Thus, among many alternative specifications, the best model (in terms of the lowest AIC, SIC, and standard error of regression values) is found as:

$$
\begin{aligned}
& \text { GROSSINF }_{t}=C+\beta_{1} I M K B_{t}+\beta_{2} I M K B_{t-4}+\beta_{3} I M K B_{t-6}+\beta_{4} R E A L I N T W P I_{t-1}+\beta_{5} R E R_{t-3} \\
& +\beta_{6} \text { BUDBAGNP }_{t-3}+\beta_{7} \text { BUDBAGNP }_{t-4}+\beta_{8} \text { IP }_{t-5}+\beta_{9} \text { OPENNESS }_{t-1} \\
& +\beta_{10} \text { GROSSINF }_{t-1}+\beta_{11} D U M 94+\beta_{12} D U M 98+\beta_{13} D U M 2001+\mathcal{E}_{t}
\end{aligned}
$$

As a further step in diagnostics, we applied heteroskedasticity ${ }^{5}$ and unit root tests. With the aim of examining whether the variance of error is affected by any of the regressors, their squares or their cross-products, we performed White Heteroskedasticity Test for the Ordinary Least Squares (oLs) regression. The test for heteroskedasticity results in homoskedasticity of the equation for the hot money model at the 0.05 significance level. Furthermore, we performed an Augmented DickeyFuller (ADF) unit root test to check the stationarity of the series. For the overall model, we found a set of I(1) variables, except the real interest rate, which was I(0). Since such kinds of sets produce an I( 0 ) disturbance term, we could regress the model without considering further differentiation for the variables to eliminate problems related with non-stationarity.

The simple ols estimates for the capital inflow equation along with the test statistics are reported in table 2.

The model estimation generates an $R^{2}$ of 0.91 . Most variables are found significant at the $1 \%$ level; yet the 1994 and 2001 dummies fail to be significant even at the $10 \%$ threshold. Thus, the aggregate effects of the crisis episodes seem to have been captured by the regressors, leaving little explanatory power to the dummies.

A rise in the value of the stock market index can be interpreted as an improvement in the perceived economic and political conditions of Turkey, revealing a positive correlation with capital inflows. Although the estimation result for the real interest rate was not found to be positive as expected, it is significant. The failure of the correct sign of this coefficient seems to be mostly due to

4. $R^{2}$ refers to the coefficient of determination (goodness of fit), which explains the variation of the dependent variable by the explanatory (independent) variables.

5. Homoskedasticity refers to the constancy of the variation of the error terms of the regression estimates. Heteroskedasticity is observed when this variation fails to be constant. 
Table 2. Financial Capital Inflows: Econometric Results

\begin{tabular}{lcc}
\hline $\begin{array}{l}\text { Dependent Variable: LOG(GROSSINF) } \\
\text { Variable }\end{array}$ & Coefficient & T-Statistic \\
\hline C & -3.78 & $-1.64^{\star}$ \\
REINTWPI(-1) & -0.003 & $-2.13^{\star *}$ \\
LOG(RER(-3)) & 1.81 & $3.83^{\star \star \star}$ \\
BUDBAGNP(-3) & -0.004 & $-3.09^{\star \star *}$ \\
BUDBAGNP(-4) & 0.006 & $3.77^{\star \star \star}$ \\
LOG(IP(-5)) & -0.93 & $-2.08^{\star \star}$ \\
LOG(IMKB(-6)) & 0.30 & $2.00^{\star *}$ \\
LOG(IMKB) & 0.23 & $2.30^{\star \star}$ \\
LOG(IMKB(-4)) & -0.39 & $-2.23^{\star *}$ \\
LOG(OPENNESS(-4)) & -1.33 & $-4.59^{\star \star *}$ \\
LOG(GROSSINF(-1)) & 0.76 & $13.78^{\star \star \star}$ \\
DUM94 & -0.06 & -0.57 \\
DUM2001 & 0.04 & 0.34 \\
DUM98 & 0.21 & $1.39^{*}$ \\
\hline
\end{tabular}

$R 2=0,91$ S.E of regression $=0.29$ Durbin-Watson Statistic $=2.05$

F-Statistic $=78.20(P$-value $=0,00)$

Note: ${ }^{* *}$ : significant at $1 \%$ and more, ${ }^{* *}$ : significant at $5 \%,{ }^{*}$ : significant at $10 \%$

(1): Calculated as $[[(1+i) /(1+p)]-1]^{*} 100$ where $i=$ compounded nominal interest rate of three month $T-b i l l s$ and $p=$ rate of increase of WPI.

the shortness of the maturity of the interest rate variable considered. On the other hand, the real exchange rate is found to be significant and its coefficient has a positive sign as expected. ${ }^{6}$

Likewise, we found that the ratio of the budget deficit to the GNP (BUDBAGNP) is a significant explanatory variable as well. Conceptually, one might argue that the BUDBAGNP and capital inflows carry a two-sided effect: capital inflows in the Turkish context are closely linked with the budget balance, and the eventual increase of public external debt ultimately raises the cost of servicing this debt. The consequent rise of the debt burden increases the public sector deficit, which in turn is securitized with issues of government debt instruments. Hence, the domestic interest rates tend to rise, attracting a new round of capital inflows. Elements of this vicious cycle are well known and are studied extensively in the Turkish literature. ${ }^{7}$ This chain of events would tend to generate a positive relationship between capital inflows and lagged budget deficits. Alternatively, the size of the budget deficit is itself regarded as a fiscal fragility indicator (see, for example, Kaminsky, Lizondo and Reinhart 1998) and therefore, any increase of BUDBAGNP is unwelcome news for the international arbiters. In addition to different signs for the different significant lags, the rather low elasticity coefficient of the BUDBAGNP variable can be taken as a suggestion of the presence of these two conflicting effects at work.

Another observation of particular interest is the negative estimate of the industrial production index. With a statistically significant coefficient of -0.93 , this result reinforces the notion that in the aftermath of financial liberalization, the expanded capital inflows failed to serve the financing

6. Note that a numerical increase in real exchange rate indicates appreciation of the Turkish lira. Theoretically, this would enable speculative gains for arbiters of foreign financial capital, hence a positive correlation coefficient is expected.

7. See, for example, Boratav, Yeldan, and Köse (2001); Ozatay (1999); Türel (1999); Selçuk and Rantanen (1996); and Zaim and Taskin (1997). 
demands of the Turkish industrial sector. On the contrary, by inducing industrialists to engage in rentier type, non-industrial activities, the Turkish post-financial liberalization period offers a typical example of the DUP (directly unproductive profit seeking) activities of the so-called rent seeking literature (for example, Bhagwati 1987; Krueger 1974), which, paradoxically, associates such activities with the corruption and venality of an excessive bureaucracy.

We found the lagged value of the trade openness variable (import plus exports as a ratio to the GNP) to be statistically significant, and yet negative. This result provides strong evidence of the detachment of the financial speculative flows from the sphere of real commercial activity. Our finding here clearly suggests that, in the post-1990 Turkish context, the volume of short-term capital flows had distortionary effects on commodity trade. This is even stronger evidence for the Rodrik and Velasco (2000) notion emphasizing the lack of a significant relationship between the volume of international trade and short-term capital flows.

Finally, the lagged value of the capital inflows is also significant and positive. This suggests the presence of strong inertia to explain current period inflows. We now turn our attention to the behaviour of private fixed investment expenditures in relation to the financial capital flows and other key macroeconomic variables.

\section{B. The Relationships among Private Investment, Financial Capital Flows, and Macroeconomic Prices}

Using the same econometric methodology as above, we now test the collinearity of private fixed investments with financial capital flows along with the selected macro variables in the Turkish context. Such an investigation is certainly not limited to a mere theoretical curiosity, as the behaviour of private fixed investments over the financial liberalization era is the ultimate object of analysis.

Capital flows are expected to have a positive impact on capital accumulation and growth in three ways: (1) they aid financing trade gaps, (2) they enhance productivity growth through transfer of foreign technology, and (3) they are expected to improve allocation of scarce funds. The validity of these channels was highlighted in a recent empirical study by the World Bank (2001). In a large sample of developing countries, the World Bank reports a significant positive relationship between aggregate foreign capital inflows and long-term growth. Even so, the report cautions against the detrimental effects of excessive volatility and highlights capital inflow volatility as a control variable having a significant negative impact on growth. The volatility aspect was also stressed in a study by Soto (2000). Soto analyzed a sample of 44 developing countries from 1986 to 1997, and reported that while FDI and portfolio inflows are significantly positively correlated with growth, bank loans display a negative correlation.

These findings on the potential detrimental effects of the volatility of short-term capital flows were already hinted at by the analytics in Grabel (1995), Stiglitz (2000), Taylor (1998), Velasco (1987), Bachetta and Wincoop (1998), and the empirical case studies narrated in a series of UNCTAD reports (see, in particular, UNCTAD 1998 and 2000) as well as in collected volumes such as Ffrench-Davis (2000), Fanelli and Medhora (1998), Larrain, Laban and Chumacero (2000), and Caprio, Honohan and Stiglitz (2001).

In the Turkish context, the most recent studies on the impact of capital inflows on aggregate spending categories are provided by Özatay and Sak (2002) and Ülengin and Yentürk (2001), and Uygur (1999) studied the patterns of aggregate private investments over the post-1989 Turkish economy using time-series econometrics. Onaran and Yentürk (2001), on the other hand, focused on the behaviour of private manufacturing investments in response to wages and profitability. 
Using time-series quarterly data from 1987 to 1997, Ulengin and Yentürk ran a series of Granger causality tests and Vector Auto-Regression impulse functions, and found that foreign savings had a positive effect on private consumption rather than creating additional resources for investment. Even though Ülengin and Yentürk's results corroborate the hypotheses of the "volatility machine" literature, the fact that they use the current account deficit as synonymous with foreign savings restricts their results only to the net effects of capital flows. This approach has the disadvantage of net capital flows having lower significance in relation to the aggregate macro categories in the Turkish context. ${ }^{8}$ We argue that the explanatory power embedded in the gross value of capital inflows - rather than their net transfers - would be richer (see also Tobin 2000 for a technical appraisal of this issue).

In the construction of our model, we have used the lagged value of the gross domestic product (GDP), the lagged value of the gross inflows of the portfolio investments by the residents and nonresidents (the time series of the dependent variable, GROssinf of the previous section), the lagged value of the real interest rate (REINTWPI), and the lagged value of the real wage rate in private manufacturing (WAGES).

Since data on the investment and wages series were available only in quarterly fashion, we have conducted our analysis using quarterly series of the above variables from January 1992 to April 2001. Data on the GROSSINF and REINTWPI are as in the model used in section A above. For the real wage rate we have used the State Planning Organization quarterly data on unit wage index in private manufacturing industry based on the index $(1992=100)$ of the production workers' hourly wages, seasonally adjusted.

Starting from six lags, we performed the method of general-to-specific again and came up with the following best model that gave the possible smallest AIC and sic by reducing the standard error of regression (all variables are in logarithms):

$$
\begin{aligned}
\text { INVPRI }_{t}=\beta_{0} & +\beta_{1} G D P_{t}+\beta_{2} G D P_{t-2}+\beta_{4} G D P_{t-4}+\beta_{5} G D P_{t-6} \\
& +\beta_{6} \text { REINTWPI }_{t-2}+\beta_{7} \text { REINTWPI }_{t-4}+\beta_{8} \text { REINTWPI I I }_{t-6} \\
& +\beta_{9} \text { WAGES }_{t-3}+\beta_{10} \text { OORSSINF }_{t-4}+\beta_{11} \text { GROSSINF }_{t-5}+\varepsilon_{t}
\end{aligned}
$$

We performed the White Heteroskedasticity Test and ADF unit root test for an initial examination of the diagnostic properties of the time series involved. The result of the White Test was homoskedasticity of the model with a 0.05 significance level. At the end of the unit root test, we found a I(1) series of explanatory variables, except for the real GDP and real interest rates, which are $I(0)$ variables. Since we had the set of $I(1)$ and $I(0)$ variables that are cointegrated, we regressed private investment on the other variables, and the result would produce residuals that are $I(0)$.

The econometric results and the implications of the model are tabulated in table 3 .

Our estimation results indicate that, except for the capital inflows, all variables are significant at $1 \%$ and above. With respect to capital inflows, private fixed investments are found to have a significant relationship only at the fourth and fifth lags, with an elasticity of 0.053 and $-\mathbf{0 . 0 5 9}$ respectively. The positive collinearity at the fourth lag was found significant only at the $10 \%$ level, whereas the negative coefficient was found to be significant at the $5 \%$ level. Without further extrapolation on the

8. As indicated above, the ratio of the current account deficit to GNP has been in the order of $1 \%$ except for the precrisis years of 1993 and 2000 . As such, the size of the current account deficit (net foreign savings) is not of a significant magnitude within the aggregate macro indicators. 
Table 3. Real Private Fixed Investments and Financial Capital Flows: Econometric Results

\begin{tabular}{|c|c|c|}
\hline $\begin{array}{l}\text { Dependent Variable: LOG(INVPRI) } \\
\text { Variable }\end{array}$ & Coefficient & T-Statistic \\
\hline $\mathrm{C}$ & 10.85 & $6.29 * * \star$ \\
\hline LOG(GDP) & 1.29 & $5.51 * * *$ \\
\hline $\operatorname{LOG}(G D P(-1))$ & -0.27 & $-4.68^{\star * *}$ \\
\hline $\operatorname{LOG}(\operatorname{GDP}(-2))$ & 1.43 & $6.10^{* \star *}$ \\
\hline $\operatorname{LOG}(G D P(-4))$ & -1.02 & $-4.84 * \star \star$ \\
\hline $\operatorname{LOG}(G D P(-6))$ & -1.49 & $-6.38 * \star \star$ \\
\hline REINTWPI(1)(-2) & 0.002 & $3.30 * * *$ \\
\hline REINTWPI(-4) & 0.002 & $3.26^{* * *}$ \\
\hline REINTWPI(-6) & 0.004 & $4.76^{\star \star \star *}$ \\
\hline LOG(WAGES(-3)) & -0.42 & $-3.22 * * *$ \\
\hline LOG(GROSSINF(-4)) & 0.05 & $1.74^{\star}$ \\
\hline LOG(GROSSINF(-5)) & -0.06 & $-2.11^{\star \star}$ \\
\hline
\end{tabular}

$R 2=0,94$ S.E. of regression $=0.06$ Durbin-Watson Statistic $=1.84$

F-Statistic $=33.03(P$-value $=0,00)$

Note: ${ }^{\star \star}$; significant at $1 \%$ and more, ${ }^{\star *}$ isignificant at $5 \%,{ }^{*}$ :significant at $10 \%$

(1): Calculated as $[((1+i) /(1+p)]-1]^{\star} 100$ where $i=$ compounded nominal interest rate of three month $T$-bills and $p=$ rate of increase of WPI.

conflicting nature of such numerical results, we interpret this econometric evidence between private fixed investments and short term capital flows as "inconclusive" at best.

In fact, a closer look at the composition of private investments discloses the underlying virulent structure of the post-1990 capital accumulation patterns of the Turkish economy. Examining the period from 1989 to 2000 , one observes that the share of private investments destined for the nontraded sectors such as housing, energy, and transportation outpace those destined for the traded sectors, especially manufacturing. The share of private manufacturing investments, in particular, is observed to suffer from a long-term decline from its peak of $42 \%$ in 1972 , to $31 \%$ in 1982 , and to $22 \%$ in 2001. On the other hand, private housing investment expenditures, after increasing their share from $25 \%$ in 1972 to $48 \%$ in 1989 , seem to stabilize at $40 \%$ throughout the 1990 s. ${ }^{9}$ The unprecedented decline of the share of manufacturing investments is further underscored in Günçavdi, Bleaney, and McKay (1996).

The level and composition of private fixed investment expenditures are shown in figure 4 . The deceleration of manufacturing investments against the expansion of non-traded sectors (housing, energy, and transportation) is clearly visible. It was this aspect of the Turkish investment patterns that led Metin-Özcan, Voyvoda, and Yeldan (2001) to comment that the main trade-off in the post-1980 Turkish economy did not occur in the crowding-out effect of public over private investments, but in the sectoral level between non-traded housing investments and investments in manufacturing.

9. See Yeldan (2001) for further sectoral detail on private investment behaviour. Metin-Ozcan, Voyvoda and Yeldan (2001) argue that the shift of emphasis from traded to non-traded fixed investments constitutes one of the main anomalies of the post-1980 export-oriented growth strategy of the Turkish economy, leading eventually the demise of the export surge by 1989. 


\section{Figure 4. Real Private Fixed Investments by Sectors}

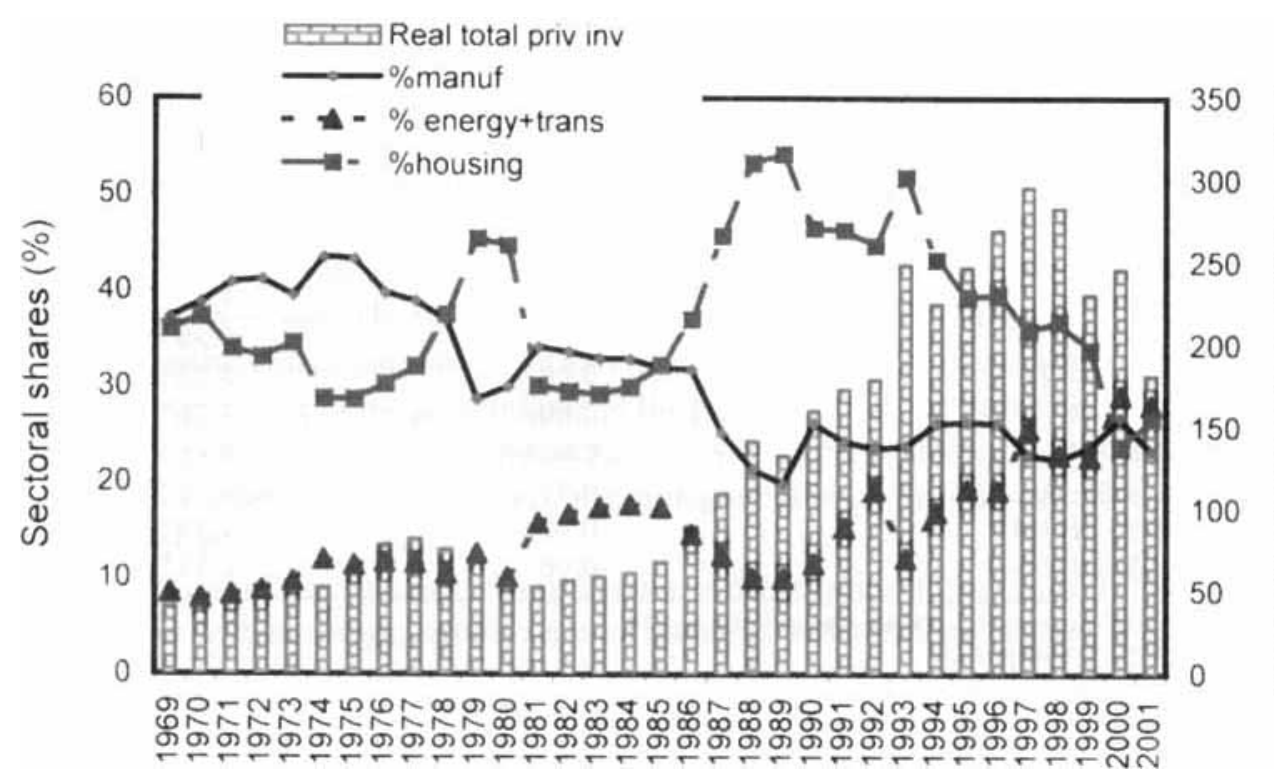

Source: State Planning Organization. Nominal values are deflated by the WPI $(1987=100)$

Thus, our econometric results, while suggesting an inconclusive association between financial capital flows and private fixed investments, nevertheless corroborate Ülengin and Yentürk's (2001) view that the increase in investments seems to have arisen from the accelerator effect of non-traded goods consumption under currency appreciation. Note that in the previous model we found a positive correlation between capital inflows and exchange rate appreciation. Due to the appreciation of the real exchange rate, the cost of imports of intermediate and capital goods decreases, enabling a rise of private investment demand.

A striking finding from our econometric investigation is the significant and relatively sizable negative correlation of private fixed investments with real wage costs. With an elasticity coefficient of -0.42 , globalized private investors seem to have abandoned the Kaleckian ${ }^{10}$ wage-led investment patterns argued by Onaran and Yentürk (2001) to be prevalent in Turkey from 1975 to 1995 . Our results suggest that at a time of currency appreciation, in order to keep their export competitiveness, investors had to rely on declining wage costs. Under the volatile and uncertain conditions of speculation-driven investment patterns, the downward flexibility of real wages has to be seen as a concomitant factor of the post-financial liberalization episodes.

Finally, we have found that real GDP has a positive relationship to investment expenditures for the same period of time, indicating that accelerator principles are at work. Although theory suggests a negative relation between private fixed investments and the interest rate, our econometric estimates fail to validate this expectation. Our intuition of what lies behind this finding is that the very shortrun fluctuations of interest rates seen are not sufficiently powerful to affect private fixed investment, whose decision making and working process takes a longer time than the maturity of the interest

10. For a thorough assessment of the Kaleckian vision of development, see, for example, Kalecki (1976). 
rates. Alternatively, a case can be made that the consistently very high real rates of interest of the 1990 s might already have exerted a significant negative influence on private investments, and that what is tested here in terms of the change in interest rates from one period to the next might not be of further importance.

\section{Conclusion}

The neo-liberal thought on financial liberalization is that an open and unregulated capital account is growth inducive, leading to the increased availability of loanable funds and enabling the transfer of foreign technology. Accordingly, freed from the strangulation of "financial repression," financial intermediaries should be able to work more efficiently, bringing savers and investors together at lower cost.

These expectations, however, have been challenged by the crisis episodes of the last two decades. Both the numerous empirical case studies and the policy lessons of the Mexican, East Asian, and, more recently, the Turkish and the Argentinean experiences revealed that the expected beneficial effects of capital inflows have been overshadowed by the adverse impacts of excessive stock market volatility and the persistence of the risk of unforeseen fluctuations in the exchange rates. In fact, large capital inflows as witnessed in recent years have posed serious dilemmas and created significant policy challenges.

This paper analyzed these issues in Turkey following its capital account liberalization in 1989. We identified capital inflows exclusively with the portfolio investments of residents and non-residents abroad and foreign credits of the banking sector; and using time-series econometrics, we searched for the macroeconomic variables that best explain the behaviour of capital inflows from 1992 to 2002. We further investigated the changing nature of the role of private investment in the postcapital account liberalization period and studied its correlation with capital flows and the key macroeconomic prices, such as the exchange rate, the real rate of interest, and real wages.

Our results suggest that financial capital inflows have a significant negative correlation with the industrial production index and trade openness, and are positively correlated with real currency appreciation. We also found that capital inflows have a positive relationship with the stock exchange index and with the one-month lagged value of inflows themselves.

Fixed private investment was found to have a mixed relationship with financial capital inflows, and we argued that any relationship that exists between the two aggregates seems to be mostly due to an accumulation pattern towards non-traded sectors via currency appreciation. The dependence of investments on exchange rate appreciation via speculative financial flows highlights the speculativeled growth path of the Turkish economy over the 1990s.

Finally, real wage costs were observed to carry a significant negative relationship with private investment. Our interpretation of this result was that at a time of currency appreciation, investors had to rely on declining wage costs in order to keep their export competitiveness. Under the volatile and uncertain conditions of speculation-driven investment patterns, the downward flexibility of real wages has to be seen as a concomitant factor of the post-financial liberalization episodes. This finding also led us to hypothesize that in order to combat the detrimental consequences of the volatile patterns of aggregate demand, financial globalization would directly cause suppression of wage levels, since under conditions of currency appreciation and increasingly high real rates of interest, the whole burden of adjustment would necessarily fall on the downward flexibility of labour costs. The detailed pursuit of this theme across other "emerging market economies" has to be seen as an agenda of future research. 


\section{REFERENCES}

Bacchetta, P. and E. Wincoop (1998) “Capital Flows to Emerging Markets: Liberalization, Overshooting, and Volatility," NBER Working Paper, No. 6530, National Bureau of Economic Research, Cambridge, MA.

Balkan, E. and E. Yeldan (1998) "Financial Liberalization in Developing Countries: The Turkish Experience," in R. Medhora and J. Fanelli, eds., Financial Liberalization in Developing Countries, London: Macmillan Press.

Bello, W., K. Malhotra, N. Bullard, and M. Mezzera (2000) "Notes on the Ascendancy and Regulation of Speculative Capital," in W. Bello, K. Malhotra, and N. Bullard, eds., Global Finance, New Thinking on Regulating Speculative Capital Markets, London and New York: Zed Books, 1-27.

Bhagwati, J. (1982) “Directly Unproductive Profit Seeking (DUP) Activities," Journal of Political Economy 90(5), Oct., 988-1002.

Boratav, K., E. Yeldan, and A. Köse (2001) "Globalization, Distribution, and Social Policy: Turkey: 1980-1998," in L. Taylor, ed., External Liberalization and Social Policy, London and New York: Oxford University Press, 317-62.

Calvo, G. (1998) "Capital Flows and Capital-Market Crises: The Simple Economics of Sudden Stops," Journal of Applied Economics I(1), Nov., 35-54.

Calvo, G., L. Leiderman and C. Reinhart (1996) "Inflows of Capital to Developing Countries in the 1990s," Journal of Economic Perspectives 10(2), 123-39.

Caprio, G., P. Honohan and J. Stiglitz (2001) Financial Liberalization: How Far? How Fast?, London: Cambridge University Press.

Diaz-Alejandro, C.F. (1985) "Good-Bye Financial Repression, Hello Financial Crash," Journal of Development Economics 19, 1-24.

Fanelli, J.M. and R. Medhora, eds. (1998) Financial Liberalization in Developing Countries, London and New York: Macmillan Press.

French-Davis, R., ed. (2000) Financial Crises in "Successful" Emerging Market Economies, Washington, DC: Brookings Institution Press.

Grabel, I. (1995) "Speculation-Led Economic Development: A Post-Keynesian Interpretation of Financial Liberalization Programmes in the Third World," International Review of Applied Economics 9(2), 127-249.

Günçavdi, O., M. Bleaney, and A. McKay (1996) "Financial Liberalisation and Private Investment: Evidence from Turkey," mimeograph, July, University of Nottingham, UK.

Kalecki, M. (1976) Essays on Developing Economies, Hassocks, uK and Atlantic Heights, NJ: Harvester Press and Humanities Press.

Kaminsky, G., L. Lizondo and C. Reinhart (1998) “Leading Indicators of Currency Crises," IMF Staff Papers 45, (Mar.), 1-48.

Krolzig, H. and D. Hendry (2001) Computer Automation of General-to-Specific Model Selection Procedures, Oxford: University of Oxford, Department of Economics.

Kruger, A. (1974) "The Political Economy of the Rent Seeking Society," American Economic Review 64(3), June, 291-303.

Larrain, F., M. Laban and R. Chumacero (2000) "What Determines Capital Flows? An Empirical Analysis for Chile," in F. Larrain, ed., Capital Flows, Capital Controls and Currency Crises, Ann Arbor: The University of Michigan Press, 61-82.

Metin-Ozcan, K., E. Voyvoda and E. Yeldan (2001) "Dynamics of Macroeconomic Adjustment in a Globalized Developing Economy: Growth, Accumulation and Distribution, Turkey 1969-1998," Canadian Journal of Development Studies 22(1), 217-53.

Onaran, O. and N. Yentürk (2001) "Do Low Wages Stimulate Investment? An Analysis of the Relationship between Distribution and Investment in Turkish Manufacturing Industry," International Review of Applied Economics 15(4), 359-74.

Onis, Z. and A. Aysan (2000) "Neoliberal Globalization, the Nation State, and Financial Crises in the SemiPeriphery: A Comparative Analysis," Third World Quarterly 29(1), 119-39.

Ozatay, F. (1999) "The 1994 Currency Crisis in Turkey," Policy Reform I(1), I-26.

- and G. Sak (2002) "Financial Liberalization in Turkey: Why Was the Impact on Growth Limited?", Emerging Markets, Finance and Trade 38(5), 6-22. 
Ozlale, U. and E. Yeldan (2002) "Measuring Exchange Rate Misalignment in Turkey," mimeograph, Department of Economics, Bilkent University, Ankara, Turkey.

Rodrik, D. and A. Velasco (2000) "Short-Term Capital Flows," Annual World Bank Conference on Development Economics, 1999, December 2000, 59-90.

Sarno, L. and M. Taylor (1999) "Hot Money, Accounting Labels and the Permanence of Capital Flows to Developing Countries: An Empirical Investigation," Journal of Development Economics 59, 337-364.

Selçuk, F. and A. Rantanen (1996) Türkiyedde Kamu Harcamalari ve Iद̧̧ Borf̧ Stoku Uzerine Gözlemler ve Mali Disiplin Uzerine Oneriler (Observations on Turkey's Public Expenditures and Domestic Debt Stock, and Recommendations over Fiscal Discipline), Istanbul: TUSIAD Publications.

Soto, M. (2000) "Capital Flows and Growth in Developing Countries: Recent Empirical Evidence," Development Center Technical Papers, No. 160, Development Center, Paris.

Stiglitz, J. (2000) "Capital Market Liberalization, Economic Growth, and Instability," World Development 28(6), 1075-86.

Taylor, L. (1998) "Lax Public Sector, Destabilizing Private Sector: Origins of Capital Market Crises," Working Paper Series III, No. 6, July, Center for Policy Analysis, New School for Social Research, New York.

Tobin, J. (2000) "Financial Globalization," World Development 28, 1101-4.

Türel, O. (1999) "Restructuring the Public Sector in Post-1980 Turkey: An Assessment," ERC Working Papers, No. 99/6, Economic Research Centre, Middle East Technical University, Ankara, Turkey.

Ulengin, B. and N. Yentürk (2001) "Impacts of Capital Inflows on Aggregate Spending Categories: The Turkish Case," Applied Economics 33, 1321-8.

UNCTAD (United Nations Conference on Trade and Development) (2000) Trade and Development Report, Geneva: United Nations Conference on Trade and Development.

(1998) Trade and Development Report, Geneva: United Nations Conference on Trade and Development.

Uygur, E. (1999) "Erratic Growth and Private Investment Behaviour in Turkey," mimeograph, Faculty of Political Science, Ankara University, Ankara, Turkey.

Velasco, A. (1987) "Financial Crises and Balance of Payments Crises: A Simple Model of Southern Cone Experience," Journal of Development Economics 27(1-2), Oct., 263-83.

Voyvoda, E. and E. Yeldan (2002) "Beyond Crisis Adjustment: Investigation of Fiscal Policy Alternatives in an OLG Model of Endogenous Growth for Turkey," paper presented at the VI Annual Middle East Technical University (METU) Conference on Economics, 10-15 September, Ankara, available on-line: <www.bilkent. edu.tr/ yeldane/>.

World Bank (2001) Global Development Finance, Washington, DC: The World Bank.

Yeldan, E. (2001) Kuresellesme Sürecinde Türkiye Ekonomisi: Bölüsüm, Birikim, Büyüme (Turkey in the Process of Globalization: Distribution, Accummulation, Growth), Istanbul: Iletisim Publications.

Yentürk, N. (1999) "Short Term Capital Inflows and Their Impact on Macroeconomic Structure: Turkey in the 1990s," The Developing Economies 37(1), 89-113.

Zaim, O. and F. Taskin (1997) "The Comparative Performance of the Public Enterprise Sector in Turkey: A Malmquist Productivity Index," Journal of Comparative Economics 25, 129-157. 